\title{
WYBRANE CZYNNIKI WPLYWAJĄCE NA PRZEBIEG PROCESU SUKCESJI W FIRMACH RODZINNYCH
}

\begin{abstract}
Firmy rodzinne ze względu na szereg specyficznych cech wyróżniających je spośród innych przedsiębiorstw są często tematem analiz $\mathrm{w}$ literaturze $\mathrm{z}$ zakresu zarządzania. Wśród różnorodnych firm występujących w gospodarce firmy rodzinne definiuje się najczęściej w oparciu o dwa główne kryteria: własność i zarządzanie. Zgodnie z takim podejściem, firmy rodzinne są to podmioty w których kontrolę własnościową sprawuje rodzina, a także (według części definicji) członkowie rodziny zajmują kluczowe stanowiska menadżerskie. Niezależnie od przyjętej definicji firmy rodzinne stanowią bardzo istotny odsetek wszystkich przedsiębiorstw $\mathrm{w}$ gospodarce. Jednym $\mathrm{z}$ istotnych problemów związanych $\mathrm{z}$ ich funkcjonowaniem jest proces sukcesji: transferu władzy i własności pomiędzy założycielami a kolejnym pokoleniem. W literaturze podkreśla się liczne trudności związane $\mathrm{z}$ efektywnym przeprowadzeniem tego procesu. Badania empiryczne wskazują, że znaczący odsetek przedsiębiorstw nie jest w stanie przetrwać procesu sukcesji. W artykule podjęto próbę analizy wybranych czynników wpływających na przebieg procesu sukcesji w firmach rodzinnych. W opracowaniu zaprezentowano definicję przedsiębiorstwa rodzinnego oraz scharakteryzowano najważniejsze fazy tworzące proces sukcesji, opisano także specyfikę procesu sukcesji w firmach rodzinnych. Dokonano również charakterystyki procesu wzrostu i rozwoju firmy rodzinnej próbując wskazać potencjalne możliwości i szanse jakie może przynieść zmiana własności i zarządzania. Podjęto również próbę wskazania głównych barier w skutecznej realizacji procesów sukcesyjnych $\mathrm{w}$ firmach rodzinnych..
\end{abstract}

Słowa kluczowe: firmy rodzinne, sukcesja, biznes rodzinny.

\section{WPROWADZENIE}

Sukcesja w przedsiębiorstwie rozumiana jako przekazywanie władzy i własności przez aktualnego właściciela następcy/następcom jest ważnym problemem, szeroko opisywanym w literaturze ekonomicznej. W przypadku firm rodzinnych proces sukcesji nabiera szczególnego znaczenia. Wynika to $\mathrm{z}$ faktu, iż często za ważny atrybut rodzinności firmy uważa się zaangażowanie członków rodziny w proces zarządzania firmą - w takiej sytuacji aby zachować rodzinny charakter biznesu sukcesorem firmy może być osoba wybrana $\mathrm{z}$ wąskiego grona kandydatów, często gorszych niż potencjalni zewnętrzni menadżerowie. Dodatkowym problemem związanym $\mathrm{z}$ przekazaniem zarządzania i własności w firmach rodzinnych w ręce kolejnego pokolenia są personalne relacje pomiędzy sukcesorami. Założyciel firmy znajduje się więc często w niełatwej sytuacji strategicznego wyboru pomiędzy zachowaniem familijnego charakteru biznesu, a maksymalizacją wartości rynkowej przedsiębiorstwa, które stworzył. W artykule podjęto

1 Dr inż. Paweł Perz, adiunkt, Zakład Finansów, Bankowości i Rachunkowości, Wydział Zarządzania, Politechnika Rzeszowska, Rzeszów, autor korespondencyjny, pperz@prz.edu.pl

${ }^{2}$ Dr inż. Adriana Kaszuba-Perz, adiunkt, Zakład Finansów, Bankowości i Rachunkowości, Wydział Zarządzania, Politechnika Rzeszowska, Rzeszów. 
próbę analizy procesu sukcesji w firmach rodzinnych, pod kątem potencjalnych barier związanych $\mathrm{z}$ realizacją tego procesu. W artykule spróbowano również wskazać na ewentualne szanse jakie mogą się pojawić w związku z sukcesją.

\section{SUKCESJA W FIRMACH RODZINYCH W ŚWIETLE LITERATURY PRZEDMIOTU}

W literaturze istnieje wiele definicji firm rodzinnych. W polskim piśmiennictwie obszerną dyskusję na temat różnych definicji firm rodzinnych można znaleźć w pracy A. Surdeja i K. Wacha ${ }^{3}$. Dla wyodrębnienia tej grupy przedsiębiorstw najczęściej wykorzystuje się kryterium własności. Według tego kryterium firma rodzinna to taka w której dominującym właścicielem są członkowie jednej rodziny. Przy czym dominujący udział nie oznacza koniecznie udziału większościowego (szczególnie kiedy mamy do czynienia z firmami średnimi i dużymi). W wielu pracach dotyczących rynku polskiego za wystarczający uważa się udział przynajmniej $25 \%{ }^{4}$. Dla rynków zagranicznych czasem przyjmowane są inne wielkości na przykład: $20 \%{ }^{5}$ lub $33 \%{ }^{6}$. Według innych definicji dodatkowe kryterium, które pozwala uznać firmą za rodzinną oprócz własności to aktywny udział członków rodziny w procesie zarządzania firmą. Według niektórych badaczy dodatkowy istotny aspekt działalności firm rodzinnych to ich ciągłość międzypokoleniowa. Donelleys ${ }^{7}$ określa firmę rodzinną ,jako tego rodzaju przedsiębiorstwo, które jest związane $\mathrm{z}$ daną rodziną przez przynajmniej dwa pokolenia, co jednocześnie wpłynęło na jego działalność i co oczywiste funkcjonowanie podmiotu wpłynęło na cele rodziny i jej sytuację finansową. Analizując różnorodne definicje można zauważyć, iż cecha "rodzinności" firmy ma wiele wymiarów, w związku z tym zamiast wyraźnego, ostrego wyodrębnienia firmy rodzinnych od pozostałych, możemy mówić raczej o pewnej stopniowalnej skali "rodzinności" w przedsiębiorstwie. Niezależnie od przyjętej definicji rola firm rodzinnych w gospodarce jest znacząca - według szacunków Komisji Eropejskiej firmy rodzinne stanowią około $60 \%$ ogółu przedsiębiorstw w gospodarce $^{8}$. Według badań przeprowadzonych w Polsce przez PARP odsetek przedsiębiorstw rodzinnych w sektorze MMSP wynosił 36\%. Przy czym firmy rodzinne stanowią 38\% mikroprzedsiębiorstw, 28\% firm małych i 14\% firm średniej wielkości. Jeśli dodatkowo włączymy do firm rodzinnych podmioty funkcjonujące jako działalność

\footnotetext{
${ }^{3}$ A. Surdej, K. Wach, Przedsiębiorstwa rodzinne wobec wyzwań sukcesji, Difin, Warszawa, 2010, s. 11-18.

${ }^{4}$ O. Kowalewski, O. Talavera, I. Stetsyuk, Influence of family involvement in management and ownership on firm performance: Evidence from Poland, Family Business Review, 2010, Vol. 23, s. 45-59.

${ }^{5}$ R. La Porta, F. Lopez-de-Silanes, A. Shleifer, Corporate ownership around the world, Journal of Finance, 1999, Vol. 54, No. 2, s. 471-517.

${ }^{6}$ E. Barth, T. Gulbrandsen, P. Schone, Family ownership and productivity: The role of ownermanagement, Journal of Corporate Finance, 2005, Vol. 11(1-2), s. 107-127.

${ }^{7}$ R. Donelley, The family business, Harvard Business Review, 1964, Vol. 42, No. 4, s. 93-105.

${ }^{8}$ Overview Of Family-Business-Relevant Issues: Research, Networks, Policy Measures And Existing Studies, European Commission, http://ec.europa.eu/DocsRoom/documents/10388/attachments/1/translations/en/renditions/pdf. (dostęp styczeń 2016).
} 
gospodarcza osoby fizycznej i nie zatrudniają pracowników ich udział osiągnął by $78 \%$ wszystkich firm sektora MMSP ${ }^{9}$.

Sukcesja jest definiowana jako proces przekazywania władzy i własności przez dotychczasowego właściciela wybranym następcom ${ }^{10}$. Sukcesja może być traktowana jako wiązka procesów, które często trwają przez wiele lat i przebiegają pomiędzy dwoma grupami: aktualnymi właścicielami $\mathrm{i}$ sukcesorami ${ }^{11}$. W literaturze bywa podkreślany szczególny aspekt tego procesu $\mathrm{w}$ odniesieniu do przedsiębiorstw rodzinnych. Wyjątkowość tego procesu dla tej grupy przedsiębiorstw wynika z faktu, iż najczęściej właściciele chcą zachować rodzinny charakter przedsiębiorstwa. To ogranicza w znaczący sposób możliwości przeprowadzenia tego procesu - nowi właściciele i zarządzający muszą wywodzić się z kręgu rodziny. W związku z tym zrozumiałe jest stanowisko . Sułkowskiego i A. Marjańskiego, według których sukcesja to ${ }^{12}$ : "szczególny problem przedsiębiorstwa rodzinnego, które ma trwać ponad generacjami lub pomimo wymieniających się generacji". Jak pisze A. Marjański, sukcesja jest często traktowana jako cecha wyróżniająca, a nawet definiująca firmy rodzinne, a dotyczy ona większości obszarów zarządzania takim podmiotem, m.in. począwszy od struktury własnościowej, strategii przedsiębiorstwa (zarówno tej ogólnej - całościowej jak i szczegółowej w zakresie chociażby zarządzania zasobami ludzkimi), metody zarządzania, a skończywszy na kulturze organizacyjnej. ${ }^{13}$ E. T. Stavrou, uważa że sukcesja jest jednym z trudniejszych i istotniejszych etapów życia firmy rodzinnej, gdyż nie można jej traktować jako jednorazowego i statycznego zdarzenia w historii takiego przedsiębiorstwa. ${ }^{14}$

Sam proces sukcesji w przedsiębiorstwie rodzinnym jest najczęściej prezentowany w formie następujących po sobie etapów. Takie podejście przedstawił m.in. K. Safin ${ }^{15}$, wyodrębniając sześć faz : fazę przedbiznesową, następnie wejście do firmy, w którym wyodrębniono fazę: wstępną funkcjonalną oraz fazę funkcjonalną - zasadniczy oraz fazę funkcjonalną zaawansowaną, związaną już z objęciem przywództwa, kolejny etap to wczesna sukcesja poprzez przejęcie roli dyrektorskich i ostatnia faza to sukcesja dojrzała - kiedy sukcesor staje się szefem - przywódcą firmy. W każdej z wymienionych faz sukcesor w różnym stopniu uczestniczy i poznaje działalność przedsiębiorstwa. Jest to niewątpliwie uwarunkowane wieloma czynnikami m.in.: przyjętym modelem

\footnotetext{
9 Firmy rodzinne $w$ polskiej gospodarce - szanse $i$ wyzwania, Polska Agencja Rozwoju Przedsiębiorczości, Warszawa 2009.

${ }^{10}$ Zob. np. J. Jeżak, W. Popczyk, A. Winnicka-Popczyk, Przedsiębiorstwo rodzinne funkcjonowanie i rozwój, Difin, Warszawa 2004.

${ }^{11}$ K. Safin, J. Pluta, Stan i kierunki badań nad procesami sukcesyjnymi w Polsce i na świecie, Przedsiębiorczość i Zarządzanie, Wydawnictwo SAN, Tom XIV, Zeszyt 6, Część I, s. 11-35.

12 Ł. Sułkowski, A. Mariański, Firmy rodzinne. Jak osiagnać sukces w sztafecie pokoleń?, Wydawnictwo Poltext, Warszawa 2009.

13 A. Marjański, Sukcesja jako wyróżnik przedsiębiorstwa rodzinnego, w: Ł. Sułkowski (red.), Firmy rodzinne - współczesne wyzwania przedsiębiorczości rodzinnej. Kierunki i strategie rozwoju., seria: Przedsiębiorczość i Zarządzanie, Tom XIII, zeszyt 7, Społeczna Akademia Nauk, Łódź 2012, s. 9-26.

${ }^{14}$ E. T. Stavrou, Succession in Family Businesses: Exploring the Ef-fects of Demographic Factors on Offspring Intentions to Join and Take Over Business, Journal of Small Business Management, 1999, Vol. 37(3), s. 43-61.

${ }^{15}$ K. Safin, Przedsiębiorstwa rodzinne - istota $i$ zachowania strategiczne, Prace Naukowe Akademii Ekonomicznej we Wrocławiu, Seria: Monografie i Opracowania Wrocław, s. 143.
} 
biznesowym, modelem wychowawczym, relacjami rodzinnymi, wiekiem następcy i przekazującego własność i kierownictwo firmą rodzinną, ilość sukcesorów, dodatkowe zdarzenia mające wpływ na dokonującą się zmianę $\mathrm{w}$ przedsiębiorstwie $\mathrm{i}$ inne. Oczywiście takiej zmianie towarzyszą często czynniki o naturze społecznej i psychologicznej. Aronoff, McClure i Ward ${ }^{16}$ podkreślają w swojej pracy znaczenie umiejętności dochodzenia do porozumienia i rozwiązywania problemów w sytuacjach konfliktowych, które mogą wystąpić pomiędzy nestorem a jednym lub kilkoma następcami.

A. Surdej oraz K. Wach dokonując przeglądu literatury zagranicznej, podsumowują iż proces sukcesji przebiega $\mathrm{w}$ trzech podstawowych etapach: inicjacyjnego - w którym identyfikuje się gotowość sukcesora do przejęcia działalności, etap przyszłościowy - w którym analizowana jest przyszła strategia firmy rodzinnej po przekazaniu jej następcy i etap trzeci przejściowy - w której kształtuje się w konkretach wizja założyciela do przeprowadzenia sukcesji. ${ }^{17}$

Sułkowski i Mariański podkreślają, iż brak planowania zwłaszcza tego szczególnego etapu jakim jest przekazania międzypokoleniowe, jest jedną z częstszych przyczyn upadku firm rodzinnych. ${ }^{18}$

\section{UWARUNKOWANIA SKUTECZNEGO PRZEBIEGU PROCESU SUKCESJI W FIRMACH RODZINNYCH}

Sukcesja $\mathrm{w}$ firmach rodzinnych może być analizowana $\mathrm{z}$ wielu różnych perspektyw: począwszy od roli jaką odgrywają $\mathrm{w}$ tej przemianie zasoby ludzkie (w roli sukcesora $\mathrm{i}$ seniora przekazującego firmę, a także menedżerów i pracowników firmy), wizerunku rynkowego firmy, przyszłej strategii przedsiębiorstwa, zmieniającej się struktury kapitałowej itd. Z cała pewnością proces przekazania firmy rodzinnej młodszemu pokoleniu może być przyczyną większych lub mniejszych zmian wewnątrz podmiotu gospodarczego. Zmiany często mają wyłącznie formalny wymiar, lecz niekiedy bywają również takie, o charakterze organizacyjnym i zarządczym. Mogą być także powiązane $\mathrm{z}$ ważniejszymi przedsięwzięciami równolegle przebiegającymi - a związanymi $\mathrm{z}$ rozszerzeniem działalności, zmianami $\mathrm{w}$ technologii, strukturze sprzedaży, czy implementacją innowacyjnych narzędzi wspomagających zarządzanie.

„Zmiana” w cyklu życia przedsiębiorstwa może być naturalnym momentem poprzedzającym przejście do kolejnego etapu, może być wywołana również poprzez kryzysy wewnętrzne lub zewnętrzne. Niewątpliwie przedsiębiorstwa $\mathrm{z}$ ugruntowaną, silna pozycją rynkową, lepiej radzą sobie z wyzwaniami wywołanymi „zmianą”, niż te które dopiero rozpoczynają swoja działalność i te które są w fazie schyłkowej. Pisze o tym m.in. B. Olszewska, zwracając jednocześnie uwagę na fakt ciągłej obserwacji otoczenia i

${ }^{16}$ C. E. Aronoff, S. L. McClure, J. L. Ward, Family Business Succession, Wydawnictwo MiP, Kraków 2012.

${ }^{17}$ A. Surdej, K. Wach, Przedsiębiorstwa rodzinne wobec wyzwań sukcesji, Difin Warszawa, 2010.

18 Ł. Sułkowski, A. Mariański, Firmy rodzinne, jak osiagnać sukces $w$ sztafecie pokoleń, Wydawnictwo Poltext, Warszawa 2009, s. 38. 
analizę, przygotowanie się na zmianę, niż bierne oczekiwanie i reakcje „pod przymusem zewnętrznym o charakterze antykryzysowym". ${ }^{19}$

Korzyści i szanse pojawiające się przed firmą rodzinną przechodzącą etap przełomu związany z sukcesją, polegają niewątpliwie na wniesieniu świeżego spojrzenia, zapału, wiedzy i większej skłonności do podejmowania ryzyka, która $\mathrm{z}$ pewnością $\mathrm{w}$ większym stopniu będzie cechowała młodsze pokolenie niż seniorów familii dotychczas zarządzających podmiotem. Warto jednak wspomnieć, iż współistnienie tych dwóch różnorodnych spojrzeń: nestora $\mathrm{z}$ doświadczeniem życiowym, znajomością relacji $\mathrm{w}$ otoczeniu przedsiębiorstwa i jego wnętrzu oraz nowoczesności i zapału sukcesorów może przyczyniać się do dynamicznego i sprawnego wzrostu takiej firmy. Należy pamiętać, że wspólny cel rodziny zarządzającej firmą staje się gwarantem stabilności w długim okresie. Zazwyczaj firmy takie nie są bowiem nastawione na krótkoterminowy sukces, lecz w ich strategii ściśle powiązanej z celami rodziny - jest najczęściej zapewnienie stabilności ekonomicznej dla przyszłych pokoleń.

Podejmując próbę określenia zagrożeń i barier w pojawiają się procesie sukcesji, możemy dokonać wstępnej ich typologii: na takie, które stoją $\mathrm{w}$ parze $\mathrm{z}$ postawą sukcesora, nestora-założyciela, oraz takie które wynikają z przebiegu samej sukcesji.

Niektóre spośród nich, zwłaszcza te które dotyczą obu stron odgrywających główną rolę w tym procesie, zostały już wcześniej wymienione pośród ogólnych czynników warunkujących etap przekazania firmy młodszemu pokoleniu. Dotyczą one zwłaszcza: cech osobowościowych, postaw, emocji towarzyszących, kompetencji obu stron, ambicji, planów itp. Zagrożenia, które występują w samym procesie mogą wynikać m.in. z niewłaściwego dobrania momentu przekazania firmy, złego zaplanowania przejęcia przez następców, niewłaściwej formy sukcesji itp.

Sukcesja wydaje się naturalnym procesem w rozwoju firmy rodzinnej. Niewątpliwie jest ona obarczona ryzykiem. Jednakże ryzyko to może mieć wydźwięk zarówno pozytywny jak i negatywny. Każda bowiem zmiana przywołuje szanse jak i możliwość wystąpienia zagrożeń, czy barier nie do pokonania. Ważne jest jednak aby przygotowując się do takiej przemiany, rozumianej jako przejście w kolejny etap rozwoju firmy rodzinnej, rozważyć wszystkie alternatywne scenariusze dalszego funkcjonowania przedsiębiorstwa. To właśnie brak planu, kompetencji lub niechęć do badania okoliczności lub skutków podejmowanych działań (w tym zwłaszcza związanych $\mathrm{z}$ przekazaniem firmy rodzinnej) może wywoływać ryzyka związane $\mathrm{z}$ tym procesem. Zatem etap sukcesji winien być realizowany $\mathrm{w}$ sposób przemyślany, uprzednio zaplanowany, poprzedzony analizą wszelkich czynników zewnętrznych i wewnętrznych, które mogłyby ten proces zakłócić. Warto również wspomnieć o dużej różnorodności modeli sukcesji, co w konsekwencji będzie warunkować jej przebieg. Pośród ważniejszych uwarunkowań wpływających na przebieg przekazania firmy pokoleniu młodszemu należy m.in. wymienić takie, które występują po stronie sukcesora:

- Chęć przejęcia firmy rodzinnej

- Stopień zainteresowania sprawami biznesowymi

- Wiedza i umiejętności

${ }^{19}$ B. Olszewska, Czynniki zmian przelomowych w przedsiębiorstwie, w: Studia i Prace Kolegium Zarządzania i Finansów, Zeszyt Naukowy 100, Szkoła Główna Handlowa w Warszawie, Warszawa 2010, s. 130-136. 
- Doświadczenie w pracy i zarządzaniu przedsiębiorstwem nabrane w okresie przedsukcesyjnym

- Chęć uczenia się i pogłębiania wiedzy

- Ilość sukcesorów i możliwości porozumiewania się pomiędzy nimi w sytuacjach konfliktowych

- Siła motywacji sprawiającej podjęcie wyzwania, jakim jest przejęcie firmy rodzinnej i jej poprowadzenia

- Pomysł na dalszy rozwój firmy i rozwój osobisty, wraz z poczuciem odpowiedzialności i satysfakcji z prowadzenia firmy rodzinnej.

Czynniki wpływające na przebieg sukcesji charakteryzujące osobę nestora - założyciela firmy rodzinnej to m.in.:

- Stopień zaufania do młodszego pokolenia przejmującego firmę,

- Chęć (potrzeba/konieczność) odsunięcia się od roli często jedynego właściciela i zarządzającego firmą rodzinną

- Lęk przed utraceniem kontroli nad firmą rodzinną

- Przekonanie o własnej nieomylności w podejmowaniu kluczowych decyzji

- Możliwości dochodzenia do kompromisu pomiędzy pokoleniami nestora i sukcesora / ów w sprawach dotyczących firmy rodzinnej

- Wyczerpanie kreatywności i brak zaangażowania w sprawy firmy.

Lewandowska, Greser i Jakubowski zwracają również uwagę na znaczenie takich barier jak: nieudolności seniora- dotychczasowego właściciela w wyborze sukcesora oraz niewłaściwe przeprowadzenie spraw spadkowych skutkujące np. brakiem możliwości opłacenia przez sukcesorów stosownych podatków. ${ }^{20}$

Kolejna grupa czynników, które mogę wpłynąć na przebieg procesu sukcesji związana jest $\mathrm{z}$ relacjami pomiędzy właścicielem a sukcesorem. Cabera-Suarez ${ }^{21}$ zwraca uwagę na kluczową rolę relacji opartych na zaufaniu i szacunku. Tego typu relacje sprzyjają skutecznemu przekazywaniu wiedzy i kapitału społecznego pomiędzy nestorem a sukcesorem lub w szerszym kontekście pomiędzy generacjami właścicieli a sukcesorów.

\section{PODSUMOWANIE}

Procesy sukcesyjne są jednym z najważniejszych wyzwań stojących przed właścicielami firm rodzinnych. Niewłaściwie przeprowadzony proces sukcesji może prowadzić do bardzo poważnych konsekwencji. Badania empiryczne wskazują na bardzo wysoki odsetek firm rodzinnych, które upadają na skutek nieudanej sukcesji. Punktem wyjścia do właściwego przeprowadzenia sukcesji jest określenie przez właściciela hierarchii celów, które chce zrealizować przy okazji tego procesu. Precyzyjne określenie celów pomoże opracować właściwy plan przeprowadzenia całego procesu w perspektywie strategicznej. Konieczna jest identyfikacja kluczowych barier, które mogą utrudnić skuteczne przeprowadzenie tego procesu. Długofalowy charakter procesów sukcesyjnych sprzyja działaniom, które stopniowo mogą ograniczać oddziaływanie lub przełamują

\footnotetext{
${ }^{20}$ A. Lewandowska, J. Greser, J. Jakubowski, Sukcesja $w$ firmie rodzinnej, w: Firma $w$ rodzinie, czy rodzina $w$ firmie. Metodologia wsparcia firm rodzinnych., Polska Agencja Rozwoju Przedsiębiorczości, Warszawa 2012, s. 121-132.

${ }^{21} \mathrm{~K}$. Cabera-Suarez, Leadership transfer and the successor's development in the family firm, The Leadership Quarterly, 2005, Vol. 16, s.71-96.
} 
istniejące bariery, zwiększając szanse na realizację celów, które miały zostać zrealizowane w wyniku sukcesji.

\section{LITERATURA}

[1] Aronoff C.E., McClure S.L., Ward J.L., Family Business Succession, Wydawnictwo MiP, Kraków 2012.

[2] Barth E., Gulbrandsen T., and Schone P., Family ownership and productivity: The role of owner-management, Journal of Corporate Finance, 2005, Vol. 11(1-2).

[3] Cabera-Suarez K., Leadership transfer and the successor's development in the family firm, The Leadership Quarterly, 2005, Vol. 16.

[4] Donelley R., The family business. Harvard Business Review, Vol. 42, No. 4, 1964.

[5] Donckels R. , Fröhl E., Are family businesses really different? European Experiences from Stratos. Family Business Review, 1991, Vol. 42, No. 4.

[6] Fleming Q., Tajniki przetrwania firmy rodzinnej, Wydawnictwo One Press Small Business, 2000.

[7] Firmy rodzinne $w$ polskiej gospodarce -szanse $i$ wyzwania, Polska Agencja Rozwoju Przedsiębiorczości, Warszawa 2009.

[8] Jeżak J., Popczyk W., Winnicka-Popczyk A., Przedsiębiorstwo rodzinne funkcjonowanie i rozwój, Difin, Warszawa 2004.

[9] Kowalewski O., Talavera O, Stetsyuk I., Influence of family involvement in management and ownership on firm performance: Evidence from Poland, Family Business Review, 2010, Vol. 23.

[10]La Porta R., Lopez-de-Silanes F., and Shleifer A., Corporate ownership around the world, 1999, Journal of Finance, Vol. 54, No. 2.

[11]Lewandowska A., Greser J. i Jakubowski J., Sukcesja $w$ firmie rodzinnej, w: Firma $w$ rodzinie, czy rodzina $w$ firmie. Metodologia wsparcia firm rodzinnych., Polska Agencja Rozwoju Przedsiębiorczości, Warszawa 2012.

[12] Marjański A., Sukcesja jako wyróżnik przedsiębiorstwa rodzinnego, w: Sułkowski Ł. (red.), Firmy rodzinne - współczesne wyzwania przedsiębiorczości rodzinnej. Kierunki i strategie rozwoju., seria: Przedsiębiorczość i Zarządzanie, Tom XIII, zeszyt 7, Społeczna Akademia Nauk, Łódź 2012.

[13] Olszewska B., Czynniki zmian przełomowych w przedsiębiorstwie, w: Studia i Prace Kolegium Zarządzania i Finansów, Zeszyt Naukowy 100, Szkoła Główna Handlowa w Warszawie, Warszawa 2010.

[14]European Commission. (2009). Overview Of Family-Business-Relevant Issues: Research, Networks, Policy Measures And Existing Studies, http://ec.europa.eu/DocsRoom/documents/10388/attachments/1/translations/ en/renditions/pdf. (dostęp lipiec 2016).

[15] Safin K., Przedsiębiorstwa rodzinne - istota $i$ zachowania strategiczne, Prace Naukowe Akademii Ekonomicznej we Wrocławiu, Seria: Monografie i Opracowania, Wrocław 2007. 
[16] Safin K., Pluta J., Stan i kierunki badań nad procesami sukcesyjnymi w Polsce $i$ na świecie, Przedsiebiorczość i Zarządzanie, Wydawnictwo SAN, Tom XIV, Zeszyt 6, Część I.

[17] Stavrou E.T., Succession in Family Businesses: Exploring the Ef-fects of Demographic Factors on Offspring Intentions to Join and Take Over Business, 'Journal of Small Business Management" 37(3):43-61 · July 1999.

[18] Sułkowski Ł., Mariański A., Firmy rodzinne, jak osiagnąć sukces w sztafecie pokoleń, Wydawnictwo Poltext, Warszawa 2009

[19] Surdej A., Wach K.., Przedsiębiorstwa rodzinne wobec wyzwań sukcesji, Difin Warszawa, 2010.

\section{SELECTED FACTORS INFLUENCING THE PROCESS OF SUCCESSION}

\section{IN FAMILY FIRMS}

Family firms due to a number of specific characteristics distinguishing them from other companies are often the subject of studies. Among the various companies in the economy, family firms are usually defined on the basis of two criteria: ownership and management. According to this approach, family firms are entities in which control is exercised by one family, and (according to some definitions) family members occupy key managerial positions. Regardless of the definition of family businesses, such companies are a significant percentage of all enterprises in the economy. One of the major issues in family business research is succession. Succession is the process of transfer ownership and power between the founders and the next generation. The literature highlights the many difficulties of effectively carrying out this process. Empirical studies indicate that a significant proportion of enterprises do not survive the process of succession. The article attempts to analyze selected factors influencing the process of succession in family businesses. In the paper the definition of the family business and most important elements of the process of succession is presented. The process of growth and development of the family firms is described. The authors try to identify opportunities that may result from the change of ownership and management of the family business.. The paper also describes major barriers of effective implementation of succession process.

Keywords: family firms, succession, family business.

DOI:10.7862/rz.2016.hss.47

Przesłano do redakcji: styczeń 2016

Przyjęto do druku: wrzesień 2016 